\title{
Use of Anabolic Steroid Altered the Liver Morphology of Rats
}

\author{
El Uso de Esteroides Anabólicos Altera la Morfología del Hígado de Ratas
}

\author{
Valéria Simões Tanasov"; Walter Krause Neto*,*; Leandro Gonçalves*; Laura Beatriz \\ Mesiano Maifrino*,"*; Romeu Rodrigues de Sousa* \& Eliane Florencio Gama*
}

TANASOV, V. S.; NETO, W. K.; GONÇALVES, L.; MAIFRINO, L. B. M.; DE SOUSA, R. R. \& GAMA, E. F. Use of anabolic steroid altered the liver morphology of rats. Int. J. Morphol., 32(3):756-760, 2014.

SUMMARY: The aim of this research was to investigate the effect of testosterone propionate administration in the liver of rats. The rats were divided in the following groups: Initial control (SC), Aged control (SE) and Anabolic group (SA). Testosterone propionate was administered three times per week during 16 weeks. Using morphoquantitative techniques, we quantified the volume densities of lobular and non-lobular parenchyma, area and number of nuclei of hepatocytes. The data were analyzed statistically using mean and standard deviation, ANOVA one-way and level of significance about $\mathrm{p} \leq 0.05$. Our results showed an increase in capillaries, perisinusoidal spaces and biliary ducts in SE group compared to SC. SA group showed a decrease in hepatic cells, non-lobular volume density and hepatocytes nuclei area, but also an increase in capillaries, perisinusoidal spaces, biliary ducts, number of hepatocytes and non-hepatocyte nuclei compared to SC. We conclude that a direct toxicity may have occurred, with consequent loss of the cells.

\section{KEY WORDS: Aging; Testosterone proprionate; Hepatic tissue; Animals.}

\section{INTRODUCTION}

The term aging is used to describe morphofunctional alterations that progressively undermine the responsiveness of individuals to the environment and the maintenance of homeostasis (Jeckel-Neto \& Cunha, 2011). The decline derived from physiological aging can be verified by functional imbalances and structural systems, and of course, the organs and tissues that make up these systems. The cellular changes lead to a decrease infunctional reserve that makes the elderly more susceptible to diseases (De Souza et al., 2008). The study of the changes caused by aging becomes relevant in that it contributes to maintaining and / or improving the quality of life of the elderly, and also for improvement of this adaptation to the environment. However, many interventions are indicated to begin before the advanced age.

The reduction of testosterone production in aging is associated with a failure response of the hypothalamicpituitary-gonadal axis, causing the testosterone levels to decline (Soares et al., 2002; Martits \& Costa, 2004). The degradation of testosterone is mainly hepatic and derivatives are excreted in the urine (Kamoun et al., 2006). Recently, physicians are prescribing anabolic steroids to treat several health conditions. However, many patients take these drugs before its necessity and at high concentrations. Although studies show the benefits of the administration of anabolic steroids, data may be conflicting, since the number of patients studied is small and the overall duration of therapy is short (Liberman, 2011).

The liver is one of the most studied organs however, only a smaller part of is conducted on the structural analysis (Ferrioli et al., 2011). According to Garcia et al. (2007), stereology is an important method to histological analysis and therefore is present in different areas of research. Morphometry not unlike stereology also provides knowledge or three-dimensional spatial structure of the study.

The purpose of the present study was to investigate the morphoquantitative effects of the administration of anabolic steroid in the liver tissue of middle age rats.

\section{MATERIAL AND METHOD}

The study was approved (protocol 015/2006) and performed at the Laboratory of Morphoquantitative Studies and Immunohistochemistry of the São Judas Tadeu University. We used male Wistar rats (Rattus norvegicus), with 13

\footnotetext{
* Laboratory of Morphoquantitative Studies and Immunohistochemistry, São Judas Tadeu University, São Paulo, Brazil.

*** Institute Dante Pazzanese of Cardiology, São Paulo, Brazil.
} 
months of age $(526.0 \pm 105.3 \mathrm{~g})$ from the animal house of the São Judas Tadeu University. During the experiment the animals were housed in boxes of polypropylene (three each) and kept under controlled environmental conditions of temperature $\left(22^{\circ} \mathrm{C}\right)$ and lighting $(12$-hour cycle of light and 12 hours dark). For all groups we provided: reference commercial diet for rats $(2.0 \mathrm{~g}$ protein $/ \mathrm{kg}$ body weight $)$ and water ad libitum.

The animals were divided into 3 groups: Group SC sedentary control $(n=5)$, Group $S E$ - aged animals that were euthanized at 16 months of age $(n=6)$, Group SA - sedentary animals that received testosterone propionate $(n=6)$.

We used a dose of $3 \mathrm{mg} / \mathrm{kg}$ bodyweight of Testosterone propionate (TP), three times per week (PERINON ®, veterinary laboratory Perini in $100 \mathrm{ml}$ containing $1 \mathrm{~g}$ of testosterone propionate and peanut oil $\mathrm{qs} 100 \mathrm{ml}$ ). This dosage is proportionally to an adult weighting $70 \mathrm{~kg}(200 \mathrm{mg}$ of testosterone propionate every three weeks). The administration of TP was done in the SA group via intramuscular applications in the right hip, from 13 months of age until the animals were euthanized at 16 months of age.

At certain ages (13 months and/or 16 months) the animals were anesthetized with intraperitoneal injection of thiopental (40 mg/kg body weight, Sigma (®, USA), euthanized, and the liver removed. The organ was then cut into small blocks, and as being an isotropic organ, in which the structures appear homogeneously, histological sections were performed randomly. The organ was fixed in $10 \%$ buffered formalin for 24 hours and then transferred to alcohol $70 \%$. After being dehydrated in increasing series of alcohols, diaphanized in xylol and embedded in paraffin, the histological blocks were cut into sections of $5 \mu \mathrm{m}$ thick each and then stained with HE (hematoxylin and eosin) for light microscopy analysis. The HE-stained slides were used to quantify: 1) Lobular parenchyma Volume Density (Vv[Lpar]), comprising: liver cells, capillaries sinusoids, perisinusoidal spaces and biliary ducts. Liver cells and sinusoids channels are illustrated in Figure 1, and non-lobular parenchyma (portal veins center-lobular spaces and blood vessels) illustrated in Figures 2 and 3,2) The nuclei area of hepatocytes, 3) the number of hepatocyte nuclei, 4) the number of nuclei of liver cells, such as Kupffer and Ito's, among others without discriminating them.

Morphology was investigated by means of stereological and morphometric parameters. For Stereology, Volume $(\mathrm{Vv})$ was estimated by the analysis of the lobular (Vv[Lpar]) and non-lobular ( $\mathrm{Vv}[\mathrm{nLpar}])$ parenchyma components. The lobular parenchyma are formed by the hepatic cells and capillaries sinusoids, perisinusoidal spaces

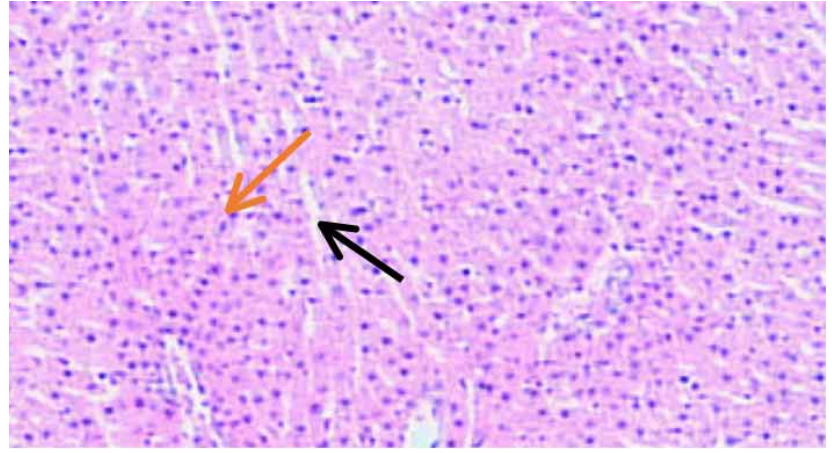

Fig. 1. Photomicrograph of Wistar rat liver (13 months) demonstrating: liver cells (hepatocytes) (black arrow) and capillary sinusoids (red arrow).

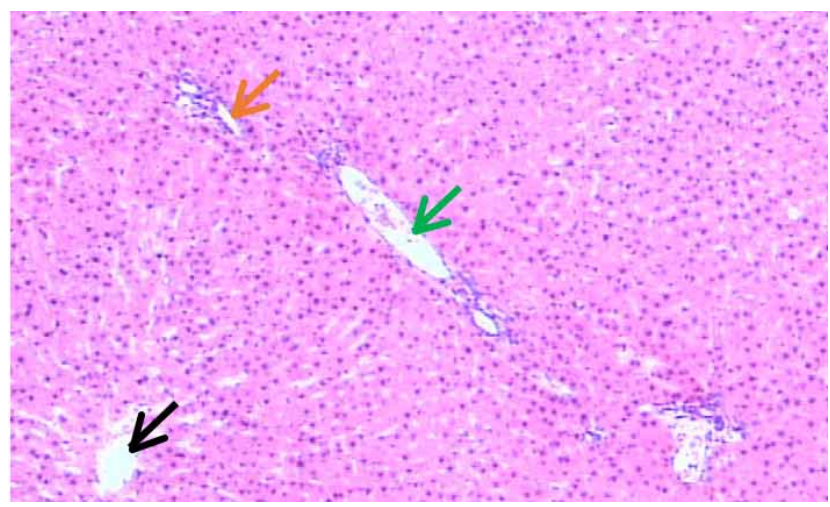

Fig. 2. Photomicrograph of Wistar rat liver ( 13 months ) showing no lobular parenchyma: portal space ( red arrow ), central lobular vein ( black arrow) and blood vessel (green arrow).

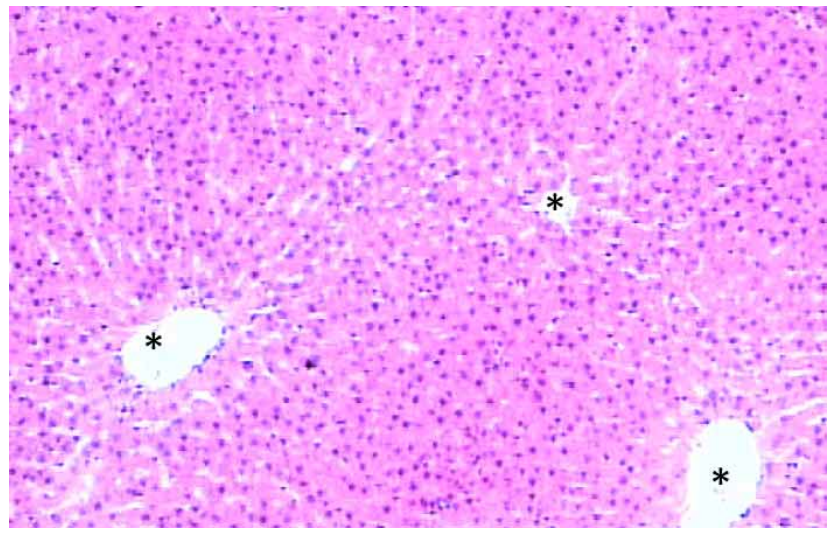

Fig. 3. Photomicrograph of Wistar rat liver ( 13 months) showing the center - lobular veins $(*)$.

and biliary ducts, and the non-lobular parenchyma, by portal spaces, veins and center-lobular branches blood vessels. Thus, we determined the occupation area of the structures by counting points as the basic law of stereology is that the relative amount of points that touch the structure is comparable to the amount of volume of this structure in the fieldtest (Mandarim-de-Lacerda, 1995). 
Table I. Volume density of liver cell for Groups SC, SE and SA.

\begin{tabular}{cccc}
\hline Groups & Mean $\#$ SD & F & P \\
\hline SC $(\mathrm{n}=5)$ & $83 \pm 13$ & 17.827 & 0.0001 \\
SE $(\mathrm{n}=6)$ & $84.6 \pm 8.3$ & & \\
SA $(\mathrm{n}=6)$ & $76.7 \pm 7.0^{*}$ & & \\
\hline
\end{tabular}

${ }^{*} \mathrm{p}<0.001$ for SA vs. SC and SE.

Table II. Volume density of capillaries sinusoids, perisinusoidal spaces and bile ducts.

\begin{tabular}{cccc}
\hline Groups & Mean $\#$ SD & F & P \\
\hline $\mathrm{SC}(\mathrm{n}=5)$ & $7.0 \pm 3.1$ & 239.44 & 0.0001 \\
$\mathrm{SE}(\mathrm{n}=6)$ & $8.9 \pm 3.2 *$ & & \\
$\mathrm{SA}(\mathrm{n}=6)$ & $18.0 \pm 4.8 * *$ & & \\
\hline${ }^{\mathrm{p}}<0.001$ SE vs. SC. & $* * \mathrm{p}<0.001$ SA vs. SC e SE. &
\end{tabular}

Table III. Volume density of lobular parenchyma (portal spaces, veins center-lobular branches of blood vessels).

\begin{tabular}{cccc}
\hline Groups & Mean \#SD & F & P \\
\hline CI $(\mathrm{n}=5)$ & $9.9 \pm 13.4$ & 5.933 & 0.003 \\
CF $(\mathrm{n}=6)$ & $6.5 \pm 8.1^{*}$ & & \\
GT $(\mathrm{n}=6)$ & $5.2 \pm 6.8 * *$ & & \\
$* \mathrm{p}<0.05$ SE vs. SC. ${ }^{* *} \mathrm{p}<0.01$ SA vs. SC. & &
\end{tabular}

Table IV. Area of the nuclei of hepatocytes $\left(\mu \mathrm{m}^{2}\right)$

\begin{tabular}{clcc}
\hline Groups & \multicolumn{1}{c}{ Mean $\#$ SD } & \multicolumn{1}{c}{ F } & P \\
\hline $\mathrm{SC}(\mathrm{n}=5)$ & $37.1 \pm 10.0$ & 3.466 & 0.031 \\
$\mathrm{SE}(\mathrm{n}=6)$ & $36.4 \pm 8.9$ & & \\
$\mathrm{SA}(\mathrm{n}=6)$ & $36.0 \pm 9.0 *$ & & \\
\hline * $<00.027 \mathrm{SC}$ vs. SA. & & &
\end{tabular}

Table V. Number of nuclei of hepatocytes

\begin{tabular}{cccc}
\hline Groups & Mean $\#$ SD & F & P \\
\hline SC $(n=5)$ & $23.2 \pm 5.6$ & 6.061 & 0.0029 \\
SE $(n=6)$ & $21.4 \pm 4.9$ & & \\
SA $(n=6)$ & $24.7 \pm 4.7^{*}$ & & \\
\hline
\end{tabular}

$* \mathrm{p}<0.01$ SA vs. SE.

The volume density ( $\mathrm{Vv})$ was calculated according to the formula: $\mathrm{Vv}=\mathrm{SPp} / \mathrm{SPt}$

Since, $\mathrm{Vv}_{\mathrm{v}}=$ volume density; $\mathrm{Pp}=$ points of the structure tested and $\mathrm{Pt}=$ total points of the test area.

The analysis of the slices for each animal was performed by photographing 20 fields with increase of 50x. Photographs were obtained by AxioVision software (version 3.1). In total there were 340 photographed fields.

For the analysis we used a test system of 300 points available in the program Image $\mathrm{J}$ (version 1.45s). The points were superimposed on images and by counting points it was possible to determine the volume density $(\mathrm{Vv})$ of the structures. Counting was performed on liver parenchyma detailing those areas occupied by the lobular and non-lobular parenchyma areas.

By means of morphometric parameters we measured: 1) the area of the hepatocytes nuclei, 2) the number of nuclei of hepatocytes and 3) the number of nuclei of liver cells not hepatocytes. We photographed 10 fields at 400x magnification obtained by AxioVision software (version 3.1). In total, there were 170 photographed fields. To quantify the area of the nuclei of hepatocytes we used the AxioVision program (version 3.1) which enables using contour of the structure under study, in other words, the core of hepatocytes, the verification area, in this case $\mathrm{mm} 2$. Then Image J program (version $1.45 \mathrm{~s}$ ) was used to quantify the number of hepatocytes and other liver cells such as Kupffer and Ito.

Data were statistically analyzed by ANOVA with a significance level $\mathrm{p} \leq 0.05$ and Tukey post-test, because the objective was to analyze variations involving three groups. Data are presented as mean \pm standard deviation. For data analysis we used SPSS, version 12.0.

\section{RESULTS}

All data are described in detail in Tables I, II, III, IV and $\mathrm{V}$.

Stereology. Lobular Parenchyma Volume Density (Vv[Lpar])

Liver Cell. Group SA presented a 7.6\% decrease compared to $\mathrm{SC}(\mathrm{p}<0.001)$. In comparison with the Group SE, SA group showed decrease of $9.3 \%(\mathrm{p}<0.001)$.

Capillaries sinusoids, bile ducts and perisinusoidal spaces. Group SC showed an occupancy rate of $3.1 \pm 7 \%$ of the test area. Group SE showed an increase of $27.1 \%$ of the area occupied by channels compared to $\mathrm{SC}(\mathrm{p}<0.001)$. Comparison of group SA with SC, also showed a significant increase of $157.1 \%$ in the area occupied by the channels $(p<0.001)$. SA Group showed an area of increased channels about $102 \%$ compared to SE group.

\section{Non-Lobular parenchyma Volume Density (Vv[nLpar])}

Portal spaces, center-lobular veins and branches of blood vessels. Group SC occupied 9.9\% \pm 13.4 of test area. Comparison of Group SE with SC showed a significant reduction of occupied area ( $\mathrm{p}<0.05$ ), occupying $34.3 \%$ less area than SC. On the other hand, SA presented a $47.5 \%$ 
decrease of occupied area compared to SC $(\mathrm{p}<0.01)$. Comparison of Groups SE and SA reached no statistically significant difference.

\section{Morphometry}

Area nuclei of hepatocytes. Analyzing the area of the nuclei of hepatocytes, the SC group had a mean of $37.1 \pm 10.0 \mu \mathrm{m}^{2}$. Comparing SA to SC group, there was a significant decrease $(\mathrm{p}<0.027)$ which corresponds to a decrease of $3.0 \%$ of the area of hepatocytes in the SA group. No significant difference was found between SE and SC, and SE and SA groups.

Number of hepatocyte nuclei. The analysis of the number of hepatocyte nuclei was performed by simple counting of the same observation in a field with an area of $11,330.4 \mu \mathrm{m}^{2}$. Comparing SC to SE, SE showed a decrease of $7.8 \%$ of hepatocyte nuclei. An increase of $6.5 \%$ was found in group SA compared to SC. However, neither showed statistical significance. SA group showed a significant increase of $15.4 \%$ in the number of hepatocyte nuclei compared to SE $(\mathrm{p}<0.01)$.

Number of nuclei of liver cells (non-hepatocytes). SC group showed an average number of $9.5 \pm 4.2$ nuclei. The Group SE presented a 5.3\% increase in the number of nuclei of liver cells (hepatocytes not) compared to SC. However, such an increase did not reach statistical significance. The SA Group also presented an increase in the number of nuclei, compared to SC Group, this time in the order of $36.8 \%$, it showed an average of $13.0 \pm 11.4$ nuclei per field. Comparing the Groups SE and SA, we observed a 30\% increase in Group SA, but we did not reach statistical significance.

\section{DISCUSSION}

Analysis of liver tissue took into account the classic way of describing liver histology. The results obtained in stereological analysis concerning volume density $(\mathrm{Vv})$ of liver parenchymal cells lobular allowed us to verify that the group that received TP had decreased Vv cells, both in relation to the group SC as the group SE, thus this change seems to be related to androgen and not with advancing age.

The analysis of the area of the nuclei of hepatocytes allows enlarged considerations. Considering that the core area decreased in the group SA, we found a possible action of TP over the nuclei of hepatocytes. It should be mentioned that the number of nuclei of hepatocytes increased in the treated group compared to the other two groups. Another fact is, if volume density and the area of hepatic cells decrease rather than an increase in the number of hepatocytes, we may infer that there was an increase in the number of cell divisions promoted by the androgen administration. This hypothesis is based on the assertion of De Souza et al. who described that during advancing age, condensation of DNA is higher by the occurrence of crosslinking which decreases the production of RNA and cell divisions. So it might have an increase of the number of cell divisions promoted by androgen. Another study that supported this hypothesis was a review article on liver regeneration, where Michalopoulos \& De Frances (1997) highlighted the role of testosterone as a mitogen for hepatocytes.

The results obtained in the stereological analysis of volume density $(\mathrm{Vv})$ of the capillary sinusoids, perisinusoidal spaces and lobular bile ducts of the liver parenchyma allowed to verify an increase in the volume density of structures in both the aged animals without administration of testosterone propionate as with animals receiving administration. Thus, both aging and the administration of androgen seem to induce a response related to the transportation lobular parenchyma. One possible explanation is that an increase in aging perisinusoidal spaces may form fibrosis, which hinders the passage of substances from the capillaries into hepatocytes. This process might even lead to hypoxia in hepatocytes and cause impairment in the transfer of substrates into hepatocytes (Le Couteur et al., 2005). However, we noticed that group SA had an increase of $157 \%$, while the group SE had modest increase of $27 \%$. This difference allows us to consider that androgen administration might have promoted more significant change in transport infrastructure in the liver parenchyma. Corroborating, Lise et al. (1999) quoted that cholestasis can be related to the use of exogenous testosterone. Considering that cholestasis involves bile ducts, significant changes found in our study might indicate that administration of TP altered the concentration of bile ducts conveyed by said. Moreover, it might have an increase in the volume of capillaries sinusoids by a hepatic congestion (Engelman et al., 2001). Bento-Silva et al. (2010) described the occurrence of hepatic congestion in rats that received administration testosterone undecanoate. However, hepatic congestion was also accompanied by an increase in the volume density of the non-lobular hepatic parenchyma, which was not observed in our analysis.

With respect to the analysis of the volume density of lobular hepatic parenchyma not constituted by structures: portals spaces, veins center-lobular and branches of blood vessels, a decrease was seen in the area occupied by the structures in both aging and in administration of androgen. In aging there is a reduction of blood flow (Le Couteur et al.), consequently the diameter of blood vessels also appeared diminished. This may explain the decrease in the area occupied by vessels observed in our study. Confirming this hypothesis, 
a study conducted by Zoli et al. (1999) found decreased hepatic blood flow, especially in people over 75 years of age. This way, since the decrease in hepatic blood flow leads to a decrease in the capacity to metabolize drugs (Zoli et $a l$.$) , longer exposure to testosterone propionate may impact$ the occurrence of side effects with other derivatives.
CONCLUSION. Given the importance of the topic of this research, more studies are needed to elucidate the effects of androgen administration in its various variants of chemical composition on the hepatic tissue structures. We concluded that the anabolic steroid exposure may cause several morphological changes in liver tissue of aged rats.

TANASOV, V. S.; NETO, W. K.; GONÇALVES, L.; MAIFRINO, L. B. M.; DE SOUSA, R. R. \& GAMA, E. F. El uso de esteroides anabólicos altera la morfología del hígado de ratas. Int. J. Morphol., 32(3):756-760, 2014.

RESUMEN: El objetivo fue investigar el efecto de la administración de propionato de testosterona en el hígado de ratas. Las ratas se dividieron en los siguientes grupos: control inicial (CI), control de Edad (CE) y grupo anabólico (GA). El propionato de testosterona se administró tres veces por semana durante 16 semanas. Utilizando técnicas morfocuantitativas, determinamos las densidades de volumen del parénquima lobular y no lobular, área y número de núcleos de los hepatocitos. Los datos fueron analizados estadísticamente con la media y desviación estándar, la prueba de ANOVA de una vía y un nivel de significación $\mathrm{p} \leq 0,05$. Nuestros resultados mostraron un aumento en los capilares, espacios perisinusoidales y conductos biliares en el grupo CE en comparación con CI. El GA mostró una disminución en las células hepáticas, la densidad de volumen no lobular y el área de los núcleos de hepatocitos, como también un aumento en los capilares, espacios perisinusoidales, conductos biliares, número de hepatocitos y núcleos no hepatocíticos en comparación AL CI. Concluimos que una toxicidad directa puede haber ocurrido, con la consiguiente pérdida de las células.

PALABRAS CLAVE: Envejecimiento; Propionato de testosterona; Tejido hepático; Animales.

\section{REFERENCES}

Bento-Silva, M. T.; Martins, M. C. C.; Torres-Leal, F. L.; Barros, T. L.; Carvalho, I. L. N. F.; Filho, H. A. C. \& Almeida, F. R. C. Effects of administering testosterone undecanoate in rats subjected to physical exercise: effects on the estrous cycle, motor behavior and morphology of the liver and kidney. Braz. J. Pharm. Sci., 46(1):79-89, 2010.

De Souza, R.; Jacob Filho, W. \& Gorzoni, M. L. Peculiaridades anatomofuncionais do idoso. In: Jacob Filho, W. \& Gorzoni, M. L. (Eds.). Geriatria e gerontologia. O que todos devem saber. São Paulo, Roca, 2008. pp.7-17.

Engelman, M. F. B.; Guidugli Neto, J.; Andrade, C. H. V.; Hernandez, R. \& Goulart, L. B. N. T. Estudo morfométrico do fígado de ratos submetidos a doses supra-fisiológicas de tiroxina. Arq. Bras. Endocrinol. Metabol., 45(2):173-9, 2001.

Ferrioli, E.; Mariguti, J. C. \& Nereida, K. C. L. Envelhecimento do aparelho digestório. In: Freitas, E. V. Tratado de geriatria e gerontologia. 3a ed. Rio de Janeiro, Guanabara Koogan, 2011.

Garcia, Y.; Breen, A.; Burugapalli, K.; Dockety, P. \& Pandit, A. Stereological methods to assess tissue response for tissueengineered scaffolds. Biomaterials, 28(2):175-86, 2007.

Jeckel-Neto, E. A. \& Cunha, G. L. Teorias biológicas do envelhecimento. In: Freitas, E. V. Tratado de geriatria e gerontologia. $3^{\text {a }}$ ed. Rio de Janeiro, Guanabara Koogan, 2011. pp. 1741.

Kamoun, P.; Lavoinne, A. \& Verneuil, H. Bioquímica e Biologia Molecular. Rio de Janeiro, Guanabara Koogan, 2006.

Le Couteur, D. G.; Fraser, R.; Hilmer, S.; Rivory, L. P. \& McLean. A.
J. The hepatic sinusoid in aging and cirrhosis: effects on hepatic substrate disposition and drug clearance. Clin. Pharmacokinet., 44(2):187-200, 2005

Liberman, S. Envelhecimento do sistema endócrino. In: Freitas, E. V. Tratado de geriatria e gerontologia. $3^{\text {a }}$ ed. Rio de Janeiro, Guanabara Koogan, 2011.

Lise, M. L. Z.; Gama e Silva, T. S.; Ferigolo. M. \& Barros, H. M. T. O abuso de esteróides anabólico-androgênicos em atletismo. Rev. Assoc. Med. Bras., 45(4):364-70, 1999.

Mandarim-de-Lacerda, C. A. Métodos quantitativos em morfologia. Rio de Janeiro, Ed. UERJ, 1995.

Martits, A. M. \& Costa, E. M. F. Hipogonadismo masculino tardio ou andropausa. Rev. Assoc. Med. Bras., 50(4):358-9, 2004.

Michalopoulos, G. K. \& DeFrances, M. C. Liver Regeneration. Science, 276(5309):60-6, 1997.

Soares, C. N.; Prouty, J. \& Poitras, J. Ocorrência e tratamento de quadros depressivos por hormônios sexuais. Rev. Bras. Psiquiatr., 24(Suppl. 1):48-54, 2002.

Zoli, M.; Magalotti, D.; Bianchi, G.; Gueli, C.; Orlandini, C.; Grimaldi, M. \& Marchesini, G. Total and functional hepatic blood flow decrease in parallel with ageing. Age Ageing, 28(1):29-33, 1999.

Correspondence to:

Walter Krause Neto

Rua Taquari

Mooca, São Paulo

BRAZIL

Received: 22-06-2013

Accepted: 15-05-2014 